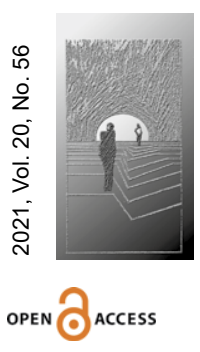

\title{
Active Forms of Conducting European Studies: Experience, Analysis, Conclusions
}

\begin{abstract}
RESEARCH OBJECTIVE: The purpose of the paper is to assess the efficiency of the active forms (Quiz, One Pager, the World Café, Visualization: Mind Mapping, Interactive lecture-discussion) used within the European studies for $\mathrm{PhD}$ students on ensuring quality of higher education.
\end{abstract}

THE RESEARCH PROBLEM AND METHODS: The empirical material of the research was collected by questionnaire with the direct participation of the authors. The respondents were asked to rate each of the active forms on a Likert scale from 1 to 5 points in order to obtain a rating scale for each of the active forms.

THE PROCESS OF ARGUMENTATION: The main professional and general competencies of PhD degree seekers (ability to analyse, evaluate and synthesize new and complex ideas; ability to apply knowledge in practical situations; ability to work in a team etc) can be developed using the active forms of training.

RESEARCH RESULTS: The study showed that active forms are effective for the European studies and development of the professional competence of PhDs.

CONCLUSIONS, INNOVATIONS, AND RECOMMENDATIONS: The active forms are promising for PhD students' training, especially for the instruction of complex knowledge and the formation of transversal competencies. No less important is the conclusion about the need to use a set of methods that together ensure the implementation of the full range of educational tasks.

$\rightarrow$ KEYWORDS: HIGHER EDUCATION, PHD STUDENTS, ENSURING QUALITY, ACTIVE FORMS

Sugerowane cytowanie: Sysoieva, S., Lokshyna, O., Protsenko, O. i Tryhub, I. (2021). Active Forms of Conducting European Studies: Experience, Analysis, Conclusions. Horyzonty Wychowania, 20(55), 133-145. DOI: 10.35765/hw.2184. 


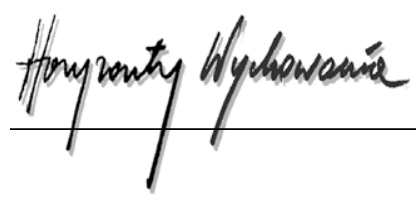

\section{STRESZCZENIE}

Aktywne formy prowadzenia studiów europejskich: doświadczenia, analiza, wnioski

CEL NAUKOWY: Celem artykułu jest ocena skuteczności form aktywnych (quiz, one pager, world café, wizualizacja: mind mapping, interaktywny wykład-dyskusja) stosowanych w ramach studiów europejskich dla doktorantów w zapewnianiu jakości edukacji szkoły wyższej.

PROBLEM I METODY BADAWCZE: Materiał empiryczny badań został zebrany za pomocą ankiety $z$ bezpośrednim udziałem autorów. Respondenci zostali poproszeni o ocenę każdej z aktywnych form w skali Likerta od 1 do 5 punktów w celu uzyskania skali ocen dla każdej z aktywnych form.

PROCES WYWODU: Główne kompetencje zawodowe i ogólne osób ubiegających się o stopień doktora (umiejętność analizowania, oceny i syntezy nowych i złożonych pomysłów; umiejętność zastosowania wiedzy w sytuacjach praktycznych; umiejętność pracy w zespole itp.) można rozwijać za pomocą aktywnych formy szkolenia.

WYNIKI ANALIZY NAUKOWEJ: Badanie wykazało, że aktywne formy są skuteczne w rozwoju kompetencji zawodowych przyszłych doktorów.

WNIOSKI, INNOWACJE I REKOMENDACJE: Aktywne formy są obiecujące w kształceniu doktorantów, zwłaszcza w nauczaniu złożonej wiedzy i kształtowaniu kompetencji przekrojowych. Nie mniej ważny jest wniosek o konieczności zastosowania zestawu metod, które łącznie zapewniają realizację pełnego zakresu zadań edukacyjnych.

\section{$\rightarrow$ SŁOWA KLUCZOWE: SZKOLNICTWO WYŻSZE, DOKTORANCI, DBANIE O JAKOŚĆ, AKTYWNE FORMY}

\section{Introducation}

The Agreement between Ukraine and the EU on Ukraine's participation in the EU Framework Programme for Research and Innovation "Horizon 2020" ("Zakon Ukrayiny", 2015) opened wide opportunities for the Ukrainian researchers. Horizon 2020 (2014-2020) was approved by the Regulation (EU) No 1291/2013 of the European Parliament and of the Council of 11 December 2013 with a view to develop European Research Area. The Horizon 2020 Zakon Ukrayiny..., (2015) focused on fostering industrial leadership and tackling societal challenges by ensuring the synergy of science, economy and society.

Ukraine's associate membership in the Programme has already provided in-depth support to Ukrainian researchers in implementing scientific ideas. Since 2014 and until July 2020, Ukrainian participants have received 182 grants worth 31,830,000 Euros. 256 Ukrainian organizations participated in Horizon 2020 in total ("Zakon Ukrayiny", 2015).

In addition to obtaining direct opportunities to produce promising scientific results for the innovative development of the national science, the Ukrainian researchers has 
got the opportunity for capacity development, the formation of the European research culture.

The Erasmus + Jean Monnet Module "Higher Education Quality and Its Expert Support: Ukraine's movement towards the European Union” (587094-EPP-1-2017-1-UA-EPPJMO-MODULE) was one of the winners. The Module had been implementing during 2017-2020 on the basis of the Borys Grinchenko Kyiv University (Svitlana Sysoieva, project coordinator, Olena Lokshyna, Olena Protsenko, Ilona Tryhub, team members) (National Erasmus+ Office in Ukraine, 2020).

The Module was aimed at providing theoretical and practical training of future doctors of philosophy $(\mathrm{PhD})$ on quality assurance and its expert support in Ukraine based on the experience of the EU (Erasmus+ Programme - Jean Monnet Activities, 2020). The project team focused its efforts on fulfilling the set goal by selecting and testing efficient technologies/methods for its implementation. We consider the received during the European studies experience on using innovative training forms and methods actual and expedient for the analysis and generalization.

The problem of developing the higher education quality assurance system and its expert support has become increasingly important in Ukraine in the last decade. Batechko (2017), Vorobyova et al., (2019) analyse the basic theoretical principles of quality assurance in higher education; Lokshyna (2018), analyses higher education quality assurance under Europeanization of Ukraine; Ohnev'yuk et al. (2015) reveal features of training experts in the field of education in Ukraine; Reheylo (2014) stresses the importance of training doctors of philosophy $(\mathrm{PhD})$ as scientific and pedagogical staff of higher qualification.

Sysoieva \& Protsenko (2020) draw attention to the need to harmonize the educational thesaurus in the process of creating the European Higher Education Area, which can be done while working on the implementation of the European framework programs. At the same time there is a positive impact on the development of general and specific skills of future doctors of philosophy who participate in the active forms of training of the "Erasmus +: Jean Monnet Module. This type of training allows professionals to use the acquired theoretical knowledge and practical skills in their professional education and promote the best EU practices among public.

The purpose of the paper is to assess the efficiency of the active forms used for the European studies within the Erasmus +: Jean Monnet Program "Higher Education Quality and Its Expert Support: Ukraine's movement towards the European Union".

\section{Research methodology}

The empirical material of the research was collected by questionnaire with the direct participation of the authors. The respondents were asked to rate each of the active forms on a Likert scale from 1 to 5 points in order to obtain a rating scale for each of the active forms. The survey was anonymous, but we asked to name the type of professional activity, as well as demographic data: gender, age, place of residence. 


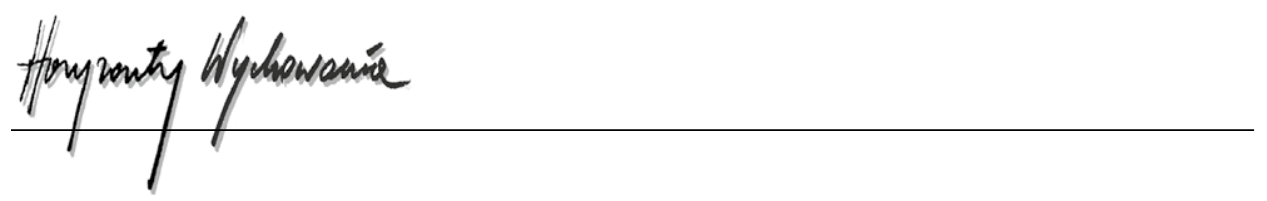

The survey involved 42 people, including $38 \mathrm{PhD}$ students and 10 research and teaching staff (some PhD students combine learning and teaching, so the total amount is greater than the number of respondents). $78 \%$ of respondents are female, $22 \%-$ male. $96 \%$ of the respondents reside in Kyiv, $3 \%$ - in Kyiv region; one respondent noted that he is from Kropyvnytskyi, but now resides in Kyiv (Table 1).

Table 1. Portrait of survey participants

\begin{tabular}{|c|c|c|c|c|c|c|c|c|}
\hline \multirow{2}{*}{ Respondents } & \multirow{2}{*}{ male } & \multirow{2}{*}{ female } & \multicolumn{3}{c|}{ Age } & \multicolumn{3}{c|}{ Region/City } \\
\cline { 4 - 9 } & & & $22-40$ & $41-55$ & over 55 & Kyiv & Kyiv region & Other \\
\hline 38 & $9(22 \%)$ & $29(78 \%)$ & $37(97 \%)$ & $1(3 \%)$ & - & $34(89 \%)$ & $3(8 \%)$ & $1(3 \%)$ \\
\hline \multicolumn{8}{|c|}{ Academic staff } \\
\hline 10 & $2(20 \%)$ & $8(80 \%)$ & $5(50 \%)$ & $4(40 \%)$ & $1(10 \%)$ & $10(100 \%)$ & - & - \\
\hline
\end{tabular}

Respondents were active participants of the intensive lessons, participated in all active forms, as well as used scientific and educational materials of the Module website and the Moodle platform.

The survey was conducted during May-June 2020.

\section{Conceptual provisions}

The theory of knowledge management, which determines the principles of their creation and use in the organization is the conceptual base of the research. The SECI model of Nonaka \& Takeuchi (1994) that shows how knowledge is shared and created in the organization was the key idea of the study. Obviously, learning within a project is different from knowledge interaction within an organization. However, all four ways that knowledge types are combined and converted, i.e. socialization, externalization, combination, internalization were considered as fundamental.

The following provisions became valuable constructs:

- it is important not only to acquire knowledge, but also to use it efficiently;

- it is important to structure the knowledge acquired by individuals;

- there is an exchange of knowledge (tacit and explicit) between members of the organization within the processes of socialization, externalization, combination and internalization;

- information technologies are effective tool for acquiring and disseminating knowledge (Nonaka \& Takeuchi, 1995).

Based on the definitions provided by the dictionaries and literature we understand

- knowledge management as the way in which knowledge is organized and used within a company, or the study of how to effectively organize and use it (Meaning of knowledge management in English, 2020), 
- quiz - a test of knowledge, especially as a competition between individuals or teams as a form of entertainment (Main meaning of quiz in English, 2020),

- a one-pager is a simple and short document that gives a high-level overview of a product, service, or a business (One Pager, 2020),

- World Café - is a creative process for facilitating collaborative dialogue and the sharing of knowledge and ideas to create a living network of conversation and action (Elliott et al., 2005),

- lecture-discussion method is the teaching method that is designed to help students understanding the organized body of knowledge, i.e. the topics that relate the facts, concepts, principles, and procedures, and make the relationship between them explicit and clear (Mutrofin et al., 2017),

- mind mapping is a visualizing technique primarily for structuring and codifying knowledge. With the aid of Mind Mapping ideas are graphically collected, structured respectively organized, and valued (Swiss Agency for Development and Cooperation, 2009).

The Salzburg Principles (Bologna seminar, 2005); Salzburg II Recommendations (2010) actualize issues of quality of higher qualification personnel training. The Principles state the importance of promoting the innovative orientation of doctoral programs, testing new forms of doctoral training based on the principles of interdisciplinarity, development of transfer, multifunctional skills of degree seekers.

The requirements for the qualification of Doctor of Philosophy in the national and higher education European areas have determined the format of learning outcomes for doctoral training of the discipline "Higher Education Quality and Its Expert Support: Ukraine's movement towards the European Union."

The discipline was aimed at formation of the following five general competencies: the ability to analyse, evaluate and synthesize new and complex ideas aimed at quality; ability to apply knowledge in practical situations based on a critical understanding of relevant issues; ability to generate new ideas (creativity); ability to search, process, analyse and use information from various sources; opportunity to work in a team (Zahal'nyy opys kompetentsiy i rezul'tativ navchannya..., 2017)

The complexity of the planned outcomes determined the format of training, which combined traditional (lectures, 60 hours), seminars, 60 hours)) and innovative (trainings, 44 hours), intensive lessons, 8 hours) forms.

The purpose of the intensives lessons was to generalize the knowledge acquired by the project participants and further develop their skills. Four intensive lessons were conducted on the following topic: Perspectives of using the experience of the Northern, Southern, Western, Eastern Europe countries in ensuring quality of higher education in Ukraine.

The ideology of the intensive lessons required the use of interactive forms/methods of training.

Quiz - two quizzes were held on the following topics: "The EU: the strategic and legal dimension of quality assurance in higher education" and "Quality assurance in higher 




education: basic concepts and terms". The purpose of using the Quiz was to repeat the material, to structure the previously acquired knowledge.

One Pager was selected to refresh the knowledge on the document "Standards and recommendations for quality assurance in the European Higher Education Area (2015)". The participants creatively presented the main ideas and sections of this document on one page.

The World Café method was used to summarize the knowledge of participants on national models of higher education quality assurance systems of the European countries and to outline the prospects of this experience for Ukraine.

Visualization: Mind Mapping technique was applied to develop an imaginary effective model for quality assurance in higher education on the example of the European countries.

Interactive lecture-discussion was used to develop the ability of participants to conduct a comparative analysis of the activities of national agencies for higher education external quality assurance and to determine the prospects for the use of positive experience in Ukraine.

\section{Results of the research analysis}

The main research question was: how the selected active forms of training are effective to obtain the Module outcomes?

In the study, we identified the following professional and general competencies of $\mathrm{PhD}$ degree seekers that can be developed using the active forms of training:

- ability to analyse, evaluate and synthesize new and complex ideas aimed at quality;

- ability to apply knowledge in practical situations based on a critical understanding of relevant issues; ability to generate new ideas (creativity);

- the ability to search, process, analyze and use information from various sources, including the Module website and the Moodle platform;

- ability to work in a team;

- ability to define basic terms;

- knowledge on higher education quality assurance systems of the European countries;

- ability to compare higher education quality assurance systems of the European countries and develop recommendations on the prospects of the European experience for Ukraine;

- ability to generalize the knowledge acquired in the process of the Module.

The "World Cafe" and "Interactive Lecture-Discussion" (204 and 192 points, respectively) were named by the respondents as the most efficient for activating the ability to analyse, evaluate and synthesize new and complex ideas aimed at quality (Table 2). The methodology of these forms provided participants with interactive interaction to solve complex problems, combine several points of view, exchange experiences and generalize. 
Table 2. Efficiency of the active forms to enhance the ability to analyse, evaluate and synthesize new and complex ideas aimed at quality

\begin{tabular}{|l|c|c|}
\hline Active forms & Final set of points & Rank place \\
\hline The World Café & 204 & 1 \\
\hline Interactive Lecture-Discussion & 192 & 2 \\
\hline Visualisation: Mind Mapping & 189 & 3 \\
\hline Quiz & 174 & 4 \\
\hline One Pager & 168 & 5 \\
\hline
\end{tabular}

The formation of participants' competencies to apply the acquired knowledge in practice is one of the missions of the intensive lessons. As evidenced by the respondents' answers the "World Café" and "Interactive Lecture-Discussion" took the highest places (Table 3).

Table 3. Efficiency of the active forms to enhance the ability to apply knowledge in practical situations based on a critical understanding of the relevant issues

\begin{tabular}{|l|c|c|}
\hline Active forms & Final set of ponts & Rank place \\
\hline The World Café & 195 & 1 \\
\hline Interactive Lecture-Discussion & 192 & 2 \\
\hline Visualisation: Mind Mapping & 189 & 3 \\
\hline One Pager & 177 & 4 \\
\hline Quiz & 165 & 5 \\
\hline
\end{tabular}

In the process of evaluating the efficiency of active forms to generate new ideas, the respondents, along with the "World Café" identified the "Visualization: Mind Mapping" technique. It is associated primarily with associative connections and is designed to stimulate cognitive activity (Table 4).

Table 4. Efficiency of the active forms to enhance the ability to generate new ideas (creativity) while working in Intensive classes

\begin{tabular}{|l|c|c|}
\hline Active forms & Final set of points & Rank place \\
\hline The World Café & 192 & 1 \\
\hline Visualisation: Mind Mapping & 189 & 2 \\
\hline One Pager & 177 & 3 \\
\hline Interactive Lecture-Discussion & 174 & 4 \\
\hline Quiz & 156 & 5 \\
\hline
\end{tabular}

Table 5 shows that the Visualization: Mind Mapping and World Café were rated by the respondents as the most efficient for enhancing the ability to search, process and use information. It should be noted that the One-Page Slide technique also ranked high place. 


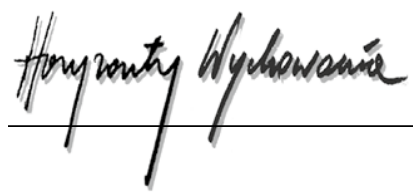

Table 5. Efficiency of the active forms to enhance the ability to generate new ideas (creativity) while working in Intensive classes

\begin{tabular}{|l|c|c|}
\hline Active forms & Final set of points & Rank place \\
\hline Visualisation: Mind Mapping & 192 & 1 \\
\hline The World Café & 189 & 2 \\
\hline One Pager & 183 & 3 \\
\hline Interactive Lecture-Discussion & 171 & 4 \\
\hline Quiz & 165 & 5 \\
\hline
\end{tabular}

The project-based learning involves teamwork, cooperation, the contribution of each participant to the result. The respondents rated highly the World Café method, which is aimed at facilitating collaborative dialogue and knowledge and ideas sharing to create a living network of conversation and action (Table 6).

Visualisation: Mind Mapping and One Pager techniques also were highly rated. Although these active forms focus primarily on structuring and codifying knowledge, it is clear that this involves close collaboration of all team members.

Table 6. Efficiency of the active forms to enhance the ability to work in a team during the lesson

\begin{tabular}{|l|c|c|}
\hline Active forms & Final set of points & Rank place \\
\hline The World Café & 204 & 1 \\
\hline Visualisation: Mind Mapping & 195 & 2 \\
\hline One Pager & 189 & 3 \\
\hline Interactive Lecture-Discussion & 174 & 4 \\
\hline Quiz & 168 & 5 \\
\hline
\end{tabular}

According to the survey results, the activation of the ability to define key terms has updated the forms of a different order. The highest rankings went to lecture-discussion used to understand and structure the body of knowledge, and quiz technique used to test knowledge acquisition (Table 7).

Table 7. Efficiency of the active forms to enhance the ability to define basic terms (accreditation, licensing, monitoring, qualification, quality, quality assurance, standards, and quality management)

\begin{tabular}{|l|c|c|}
\hline Active forms & Final set of points & Rank place \\
\hline Quiz & 204 & 1 \\
\hline Interactive Lecture-Discussion & 192 & 2 \\
\hline The World Café & 174 & 3 \\
\hline One Pager & 174 & 4 \\
\hline Visualisation: Mind Mapping & 171 & 5 \\
\hline
\end{tabular}


The transmission of knowledge about the higher education quality assurance systems in the European countries is the main task of the Module. Therefore, the intensification of this knowledge, which was transmitted to the project participants at lectures and seminars, was considered an important task during the intensive lessons. According to the respondents/ answers, virtually all the active forms proved to be efficient for this task (Table 8).

Table 8. Efficiency of the active forms to enhance knowledge about higher education quality assurance systems of the European countries

\begin{tabular}{|l|c|c|}
\hline Active forms & Final set of points & Rank place \\
\hline The World Café & 198 & 1 \\
\hline Quiz & 189 & 2 \\
\hline Interactive Lecture-Discussion & 189 & 3 \\
\hline Visualisation: Mind Mapping & 189 & 4 \\
\hline One Pager & 186 & 5 \\
\hline
\end{tabular}

The comparative research requires a set of special skills, including critical analysis, the ability to distinguish common and different characteristics, generalizations, formulation of conclusions and recommendations. Table 9 shows that the respondents the ranked highly the active forms that, on the one hand, activate the ability to structure knowledge, build a system of relationship between the facts, concepts, principles, and procedures (lecture-discussion), and on the other hand, activate the ability to generate ideas (the World Café).

Table 9. Efficiency of the active forms to enhance the ability to compare quality higher education assurance systems of the European countries and develop recommendations on the prospects of the European experience for Ukraine

\begin{tabular}{|l|c|c|}
\hline Active forms & Final set of points & Rank place \\
\hline The World Café & 201 & 1 \\
\hline Visualisation: Mind Mapping & 186 & 2 \\
\hline Interactive Lecture-Discussion & 177 & 3 \\
\hline One Pager & 174 & 4 \\
\hline Quiz & 153 & 5 \\
\hline
\end{tabular}

Table 10 shows that the World Café, Visualization: Mind Mapping and One Pager technologies got high ranks for summarizing the knowledge and skills acquired within the Module. 


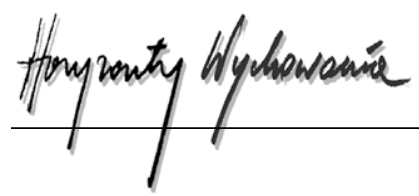

Table 10. Efficiency of the active forms to enhance the ability to compare quality higher education assurance systems of the European countries and develop recommendations on the prospects of the European experience for Ukraine

\begin{tabular}{|l|c|c|}
\hline Active forms & Final set of points & Rank place \\
\hline The World Café & 198 & 1 \\
\hline Visualisation: Mind Mapping & 183 & 2 \\
\hline One Pager & 183 & 3 \\
\hline Interactive Lecture-Discussion & 177 & 4 \\
\hline Quiz & 171 & 5 \\
\hline
\end{tabular}

According to the Bloom's Taxonomy there are six levels of cognitive learning: remembering, understanding, applying, analysing, evaluating, and creating. The results of the survey showed that the quiz and interactive lecture-discussion were ranked as the most efficient forms for the development of knowledge and understanding as less complex levels of thinking. Thus, to enhance the ability to define key terms (accreditation, licensing, monitoring, qualification, quality, quality assurance, standards, quality management), these technologies took the first two places (with 204 and 192 points, respectively) (Table 7).

The World Cafe method and Visualization technique were ranked as efficient for more complex levels of thinking (analysis, synthesis, evaluation). It is the World Cafe method that ranked the first place (204 points) for the development of the ability to analyse, evaluate and synthesise new and complex ideas aimed at quality (Table 1) and (201 points) to enhance the ability to compare higher education quality assurance systems in the European countries and develop recommendations on the prospects of the European experience for Ukraine (Table 8).

According to the results of the study, the World Café method and Visualization technique are also extremely efficient for the development of general competencies of $\mathrm{PhD}$ students.

Thus, the respondents rated them highly, putting them in 1st and 2nd places for developing the ability to apply knowledge in practical situations based on a critical understanding of relevant issues (with 192 and 189 points, respectively) (Table 2), the ability to work in a team (204 and 195 points) (Table 5), creativity development (192 and 189 points) (Table 3).

In our opinion, the respondents underestimated the One Pager technique, which was used to repeat the topic "Standards and recommendations for quality assurance in the European Higher Education Area." One-pager provides a general, concise overview of information and requires conciseness and capacity in the text, the use of illustrative materials, and therefore develops the ability to systematise, integrate, design information, as well as creativity and ability to apply knowledge in practical situations. Perhaps the not-too-high scores can be explained by its novelty for education. One-Pager is better known in business and is just beginning to be used for the education purposes. 
Fig. 1 shows the consolidated vision of the respondents on the efficiency of the active forms for teaching the European studies within the Module "Higher Education Quality and Its Expert Support: Ukraine's movement towards the European Union”.

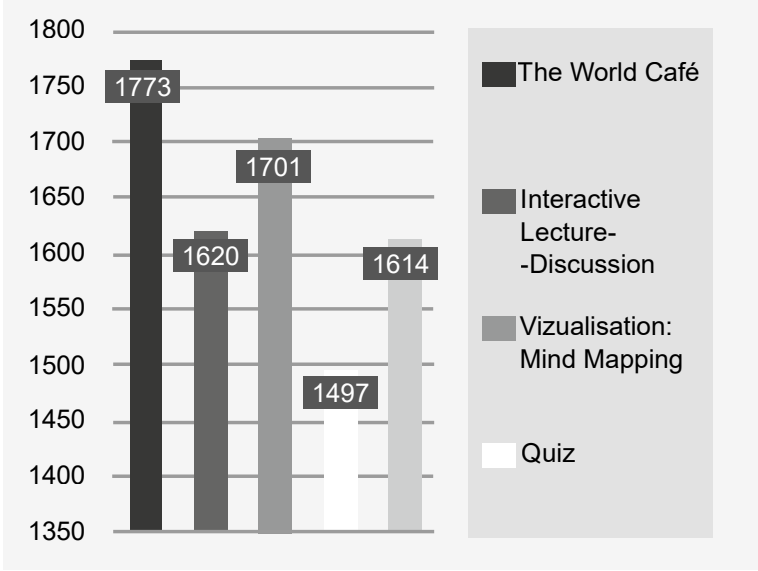

Fig. 1. Efficiency of the active forms for teaching the European studies within the Module "Higher Education Quality and Its Expert Support: Ukraine's movement towards the European Union"

\section{Conclusions and prospects for further research}

Generalization of the obtained results allowed us to make several important conclusions.

The multidimensionality of knowledge in the modern world (tacit and explicit, declarative, epistemic and procedural) necessitates the use of complex forms in the learning process. Complexity is especially relevant for teaching the European studies for PhD students. The subject of the European studies in the context of higher education quality and its expert support involves the formation of skills of comparative analysis and critical thinking, the ability to apply knowledge in practical situations, to work in a team, etc.

The research showed that the active forms are efficient for the European studies. Obviously, the used forms differ in their characteristics.

The lecture-discussion is a method that is traditionally used in the learning process to transfer and structure knowledge. In the Module the lecture-discussion was used to transfer knowledge about quality assurance systems in higher education in European countries. The discussion allowed making the participants' experience to better master the complex material on the features of education quality assurance systems.

The quiz is also an educational technology that is widely used to consolidate the studied material. It proved to be especially efficient for consolidating the knowledge acquired by the Module participants in the course of lectures and seminars on the basic terms and categories. 


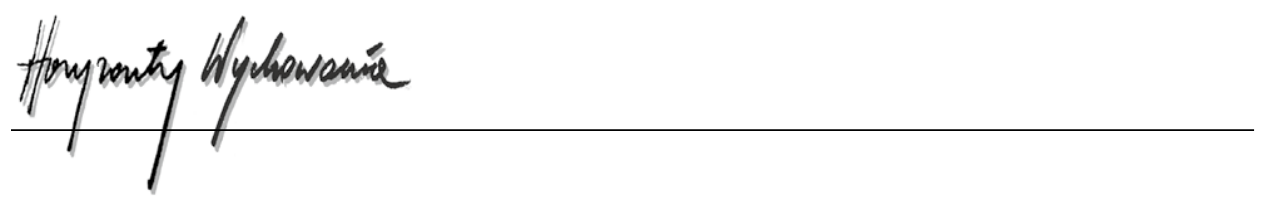

The One Pager, which is commonly used in business to present an overview of a product/service, has also proven its efficiency in generating ideas in a Module format.

The knowledge management methods - The World Café and Visualization: Mind Mapping - have been assessed by the respondents as especially efficient. This emphasizes that knowledge management methods are promising for PhD students' training, especially for the instruction of complex knowledge and the formation of transversal competencies.

No less important is the conclusion about the need to use a set of methods that together ensure the implementation of the full range of educational tasks.

Further research should include the study of digitization of the PhD students' training at the universities.

\section{BIBLIOGRAPHY}

Batechko, N. (2017) Phenomenon of the quality of education in modern scientific discourse. Educological Discourse, 3-4, 1-16.

Bologna seminar on "Doctoral Programmes for the European Knowledge Society": Conclusions and recommendations (Salzburg, 3-5 February 2005). (2005). https://eua.eu/downloads/publications/salzburg\%20recommendations\%202005.pdf

Elliott, J., Heesterbeek, S., Lukensmeyer, C.J. \& Slocum, N. (2005). Foundation participatory methods toolkit. Belgian Advertising (B.AD).

Erasmus+ Programme - Jean Monnet Activities. (2020). Module "Higher Education Quality and Its Expert Support: Ukraine's movement towards the European Union”. http://heqes.kubg.edu.ua/ en/category/home/ Accessed 10 Dec 2020

Horizon 2020 (Ministry of Education and Science of Ukraine, 2020), https://mon.gov.ua/eng/tag/ gorizont-2020 Accessed 10 Dec 2020

Lokshyna, O. (2018), Zabezpechennya yakosti vyshhoyi osvity v umovax yevropeyizaciyi Ukrayiny (Quality assurance of higher education under Europeanization of Ukraine). Continuing Professional Education: Theory and Practice, 3-4, 127-132. doi:10.28925/1609-8595.2018.3-4.127132

Main meanings of quiz in English. (2020). Lexico. https://www.lexico.com/definition/quiz

Meaning of knowledge management in English. (2020). Cambridge dictionary. https://dictionary. cambridge.org/dictionary/english/knowledge-management

Mutrofin, Degeng, N.S., Ardhana, W. \& Setyosari, P. (2017). The effect of instructional methods (lecture-discussion versus group discussion) and teaching talent on teacher trainees student learning outcomes. Journal of Education and Practice, 8(9), 203-209.

National Erasmus+ Office in Ukraine. (2020). Higher Education Quality and Its Expert Support: Ukraine's movement towards the European Union. The list of projects Jean Monnet. https:// erasmusplus.org.ua/en/projects/jean-monnet/1877-higher-education-quality-and-its-expert-support-ukraine-s-movement-towards-the-european-union.html

Nonaka, I. \& Takeuchi, K. (1995). The knowledge creating company. Oxford University Press.

Ohnev'yuk, V.O., Sysoyeva, S.O., Zhyl'tsov, O.B., Kozak, L.V., Kuz'menko, O.M., Tryhub, I.I., Halyts'ka, M.M., Mazur, N.P., Pobirchenko, N.A., Ryabenko, V.O., Zel'man, M. \& Kotsur, O.O. (2015). Osvitolohiya: pidhotovka ekspertiv u haluzi osvity (Educology: training of experts in the field of education). Edelweiss Publishing Company.

One Pager. (2020). Urban Dictionary. https://www.urbandictionary.com/define.php?term=One\%20 Pager 
Regulation (EU) No 1291/2013 of the European Parliament and of the Council of 11 December 2013 establishing Horizon 2020 - the Framework Programme for Research and Innovation (2014-2020) and repealing Decision No 1982/2006/EC (Text with EEA relevance). (2013). OJ L 347, 104-173.

Reheylo, I. (2014). Pidhotovka naukovykh i naukovo-pedahohichnykh kadriv vyshchoyi kvalifikatsiyi $v$ Ukrayini $u X X$ - pochatku XXI stolittya (Training of scientific and scientific-pedagogical staff of higher qualification in Ukraine in the XX - early XXI century). Education of Ukraine.

Salzburg II recommendations (2010, 29 October). European University Association. https://eua.eu/ resources/publications/615:salzburg-ii---recommendations.html

Swiss Agency for Development and Cooperation (SDC). (2009). Knowledge Management Toolkit. https://usaidlearninglab.org/sites/default/files/resource/files/SDC-KM-Toolkit.pdf

Sysoieva, S. \& Protsenko, O. (2020). Learning outcomes for module Jean Monnet: an experience in Ukraine. Steps to improve quality. Continuing Professional Education: Theory and Practice, 3, 87-94. doi:10.28925/1609-8595.2020.3.10

Vorobyova, O., Debych, M., Luhovyy, V., Orzhel', O., Slyusarenko, O., Talanova, Zh. \& Tryma, K. (2019). Analiz providnoho vitchyznyanoho ta zarubizhnoho dosvidu shchodo otsinyuvannya yakosti vyshchoyi osvity $v$ umovakh yevrointehratsiyi: analitychni materialy (Analysis of the leading domestic and foreign experience in assessing the quality of higher education in terms of European integration: Analytical materials) (2nd part, preprint). Institute of Higher Education of the National Academy of Pedagogical Sciences of Ukraine.

Zahal'nyy opys kompetentsiy i rezul'tativ navchannya dlya doktors'koho rivnya (PhD) pidhotvky z dystsypliny "Yakist' vyshchoyi osvity ta yiyi ekspertna pidtrymka: perekhid Ukrayiny do Yevropeys'koho Soyuzu" (General description of competencies and learning outcomes for doctoral level (Phd) education training "Quality of Higher Education and its Expert Support: Ukraine's Transition to the EU”). (2017). Erasmus+ Programme - Jean Monnet Activities. http:// heqes.kubg.edu.ua/wp-content/uploads/2017/10/A_GENERALISED_DES_Ukr.pdf

Zakon Ukrayiny Pro ratyfikatsiyu Uhody mizh Ukrayinoyu i Yevropeys'kym Soyuzom pro uchast' Ukrayiny u Ramkoviy prohrami Yevropeys'koho Soyuzu z naukovykh doslidzhen' ta innovatsiy "Horyzont 2020" (Law of Ukraine on ratification of the Agreement between Ukraine and the European Union on Ukraine's participation in the Framework Program of the European Union for Research and Innovation "Horizon 2020"). (2015). VVR. 35, 349.

Copyright and License

This article is published under the terms of the Creative Commons Attribution - NoDerivs (CC BY- ND 4.0) License http://creativecommons.org/licenses/by-nd/4.0/ 